\title{
The Church in Sierra Leone: Response and Mission during and after Covid-19 Pandemic
}

\author{
Prince Sorie Conteh, ${ }^{1}$ \\ 1 Ernest Bai Koroma University of Science and Technology, Sierra Leone.
}

\begin{abstract}
COVID-19 is the acronymic name for Coronavirus disease which broke out in December 2019. The church as progenitor of care and love, is expected to play a crucial and lasting role in dealing with this pandemic. This paper discusses the church's spiritual and practical response and mission during and after COVID-19. In terms of the church's spiritual response and mission, its theology and teachings too should be pragmatic. The church should put in action - by the process of contextualising theology - bringing the gospel to the life-situation of the people. God is not absent in this situation. The church's belief in a loving God helps to make sense of and cope with the coronavirus outbreak. In terms of the church's practical response and mission, the church can play a major role in saving lives and reducing illness related to COVID-19 by adhering to the preventive measures and recommendations by the government and health experts.
\end{abstract}

Correspondence Prince Sorie Conteh Email: psconteh@ebkustsl.edu.sl

Publication History Received 12th October 2020, Accepted 14th December 2020, Published online 22nd December 2020.

Keywords: Corona Virus (COVID-19), Church mission

C 2020 The Author(s). Published and Maintained by Noyam Publishers.

This is an open access article under the CCBY license (http://creativecommons.org/licenses/by/4.0/).

\section{INTRODUCTION}

This paper is a response to the Call for Papers by the Ecumenical Desk of the Council of Churches in Sierra Leone in June 2020 on the subject, "The Church in Post Covid-19 Sierra Leone." As COVID-19 is on the rampage, the aforementioned Desk believes that theologians should make their contributions to scholarship in practical areas of human engagement.Writing as is widely known, teaches how to make sense of oneself, the community and world; to serve as a challenge to learn, and to grow.

There is in extant a plethora of writings and published works in both print and electronics on the church's and faith-based organizations responses to COVID-19. It is impressive to see how religions are responding and disseminating their actions. This initiative by the Ecumenical Desk of the Council of Churches in Sierra Leone is a crucial contribution to the advancement of the global and religious discourse on COVID-19. To this, this Author is privileged to contribute.

On 11 February 2020, the World Health Organisation (WHO) announced an acronymic name for CORONA VIRUS as COVID-19. The 'CO' stands for Corona, 'VI' for Virus, and 'D' for Disease, and '19' for 2019 the year the outbreak was reported. According to Medscape, ${ }^{1}$ COVID-19 was declared a global pandemic by WHO on 11 March 2020. Since the outbreak of the Virus, many deaths have been reported. Numerous television stations display daily statistical updates on persons infected, quarantined, those that have recovered, and dead. COVID-19 has also caused states of emergency, nation-wide lock downs, travel bans, borders and closure of most public institutions, and huge strain on national and global economies.

As a pandemic, COVID-19 threatens life, economy, security and social relations around the world. It is a deadly unseen predator. Religious groups and institutions are looked-up to for comfort and solace during this time of crisis and devastation. The church is expected to play a crucial role in alleviating fear and suffering of people, and in

\footnotetext{
WHO," UN releases US\$15 million to help vulnerable countries battle the spread of the coronavirus," accessed June 7, 2020.

https://www.who.int/news/item/01-03-2020-un-releases-us-15-million-to-help-vulnerable-countries-battle-the-spread-of-the-coronavirus
} 
bringing hope and faith to all peoples.

The churches in Sierra Leone continue to do their best by disseminating the Word and edifying Christians through print, broadcast, and electronic media. Some denominations have also bought up the opportunity to serve others in pursuant of Galatians 6.10 which says, "While we have opportunity, let us do good to all men, and especially to those who are of the household of the faith" (NRSV). So churches in Sierra Leone are seen providing spiritual, emotional, medical and social support to their congregations.

This paper, as the church in Sierra Leone continues to impress and emphasize the love of God during this challenging time, provides a contour in responding and understanding the Christian mission during and after COVID-19. As Christians, after exploring individual needs and the needs of the society and world, it is helpful to enquire about them from a faith perspective. Social analysis must be accompanied by an insightful theological analysis. Contextual Theology demands that Christians learn to formulate faith questions about contemporary issues and experiences. The church must ask the following faith questions:

1. What is the appropriate Christian response to COVID-19?

2. How can the gospel be presented in a meaningful way in this situation?

3. How could this situation contribute more effectively to establishing the kingdom of God?

4. What Christian values would help transform this situation for the better?

\section{Relevance of Contextual Theology during and after Covid-19}

Contextual Theology is the way Christians apply the message of the Bible to personal life, the wider spectrum of social, cultural, historical, political, religious, economic and scientific contexts. ${ }^{2}$ Contextualization, as S Bergman states, "is a vivid interaction between the gospel and the very reality where people are."3 Rather than conceiving theology as something concrete and permanent, it should be conceived as pragmatic - an activity, a process, a way of living. As such, the church should not only be structured by the teachings of the Bible, but its action - by the process of contextualising theology - bringing the gospel to the life-situation of the people. ${ }^{4}$ Christians must never forget that the Bible and Church teaching remain as a standard by which to judge attempts at doing theology. So what is the relevance of the Bible to COVID-19? The subsequent paragraphs look at some approaches in contextualising the message of God. Many Christians have used the Translation Approach to portray the relevance of the Bible to COVD-19. The translation approach is the adoption by, or accommodation of the Bible to, a particular situation. In this case, "it is crucial that the message of the gospel remains unchanged. However, the translation model does not intend, or even encourage, the literal translation of biblical and theological terminologies." In other words, the translation approach must preserve the message of Bible while adapting faith expressions to a particular context.

COVID-19 compels Christians to learn from Bible characters, who turned their attention to scripture to understand the agency of God in times of disaster as a direction for their own times. The hand of God is seen in the story of the plagues upon Pharaoh and Egypt at the time of the Hebrews' deliverance from slavery (Exo 7:14-12:26). Through this episode bible readers can see how God cares for the world during difficult times. The ten plagues caused economic, natural and personal hardship and devastation. However, they provided an opportunity for Pharaoh and the Hebrew people to see God's omnipotence over creation and their own lives. In relation to Pharaoh's stubbornness, God said to Pharaoh in Exodus 9:15-16:

For by now I could have stretched out my hand and struck you and your people with pestilence, and you would have been cut off from the earth. But this is why I have let you live: to show you my power, and to make my name resound through all the earth (NRSV).

From the Exodus 7:15-16, it can rightly be said that the ten plagues were not punishments. They were an invitation to know God: "The Egyptians shall know that I am the Lord, when I stretch out my hand against Egypt and bring the Israelites out from among them" (NRSV). Jesus shows that the blindness from birth of the man in John 9 was God's intention to reveal himself (John 9:3).

Calamity is not a time for the Church to exude fear and unbelief. Even though 'we walk through the darkest valley, we should fear no harm '(Psa. 23:4). Christians are further assured that:

Whoever dwells in the shelter of the Most High will rest in the shadow of the Almighty. ${ }^{2}$ I will say of the LoRD,

"He is my refuge and my fortress, my God, in whom I trust." " You will not fear the terror of night, nor the arrow that flies by day, ${ }^{6}$ nor the pestilence that stalks in the darkness, nor the plague that destroys at midday. ${ }^{9}$ If you say, "The LoRD is my refuge," and you make the Most High your dwelling (Psa. 91:1, 2, 5, 6, 9 NRSV).

\footnotetext{
Stephen B. Bevans, Models of Contextual Theology Revised \& Expanded Edition (Maryknoll, NY: Orbis Books, 2005), 2.

Stefan Bergman, God in Context: A Survey of the Contextual Theology (UK: Ashgate Publishing Limited, 2000), 3.

Dean Flemming, Contextualization in the New Testament: Patterns for Theology and Mission (Downers Grove, IL: Intervarsity Press, 2005$), 296$.

Samuel C Lee, "Theology in context." (2015): 2, accessed June 7, 2020.http://www.samlee.org/iSam/Home/Entries/2014/7/24 Theology in Context.html
} 
Instead of fear, the Church must respond through the witness of her actions. Actions from the Christian recognition of its participation in God's care of the world through committed participation in Christ's ministry. The Christian witness is refusing to allow fear have dominion leading to a lack of concern towards the plight of a neighbour.

In this regard, Christians have also used the Praxis Approach in contextualizing the message of the Bible. This approach is about theology in practice or in action. It argues that theology is best done as Christians reflect on their practice of the faith. It is about "one's action within a particular situation, e.g. experience, culture, social location, social change to which one contributes and re-reading of the Bible and Christian traditions in light of one's present situation in order to bring positive change through committed and intelligent action (praxis)." ${ }^{\prime}$ In this approach, scriptures and theologies are therefore constantly being reinterpreted and applied within a given situation.

COVID-19 is global pandemic, in that regard, as Christians in Sierra Leone contextualise and apply the Bible message to the country's situation, which is the immediate context, they must not forget about the world, which is the wider context. The Transcendental Approach emphasises on what is called the personal view of human experience. When groups of people have a shared or the same experience, then they can speak of a general experience. For example, an American and an African may be different in their cultural and social issues, but there are times they face some issues that all human beings experience regardless of circumstances and background. At this time, regardless of culture or status, the entire world is experiencing COVID-19. This experience transcends all cultures and societies. People all over the world are basically having the same experience. So the Christian message must be Transcendental. As P Gibbs puts it, "true Christianity is found in openness to the diversity of particular situations. Nevertheless grassroots Christian communities are part of the wider Church community and should value ecclesial and doctrinal unity."”

\section{Relevance of Theodicy during after Covid-19}

Theodicy is from the Greek, Theos, "God" and dike, "justice/righteousness." It is the vindication of divine providence in the view of the existence of evil. As such, Theodicy tries to explain why a perfectly good, almighty, and all-knowing God allows evil in the world. Having studied the situation the Christian or community engaged in contextual theology formulates a relevant faith question and responds to that question drawing on scripture and church teaching. When disasters like COVID-19 occur, as Christians:

\section{Where is God in this situation?}

JC Lennox in his book titled: Where is God in a Coronavirus World? discusses how belief in a loving God helps humanity to make sense of and cope with the coronavirus outbreak. People are living through a unique, era-defining period. Traditional certainties have gone, whatever the view of the world and whatever beliefs there are. The coronavirus pandemic and its effects are perplexing and unsettling for everyone. How does mankind begin to think it through and cope with it? The book examines the coronavirus in light of various belief systems and shows how the Christian worldview not only helps make sense of it, but also offers a sure and certain hope to cling to. The author presents the biblical view of natural evil. Using the coronavirus crisis as his point of departure, he demonstrates that God is allloving and all-powerful and not the author of evil. ${ }^{8}$

In Coronavirus and Christ, Piper exhorts Christians to stand on the solid Rock, who is Jesus Christ, in whom souls can be sustained by the sovereign God who ordains, governs, and reigns over all things to accomplish his wise and good purposes for those who trust in him. Piper offers the following six answers to the question: What is God doing through the Coronavirus?: ${ }^{9}$

- ANSWER 1. God is giving the world in the coronavirus outbreak, as in all other calamities, a physical picture of the moral horror and spiritual ugliness of God-belittling $\sin .^{10}$

- ANSWER 2. Some people will be infected with the coronavirus as a specific judgment from God because of their sinful attitudes and actions. ${ }^{11}$

- ANSWER 3. The coronavirus is a God-given wake-up call to be ready for the second coming of Christ. ${ }^{12}$

- ANSWER 4. The coronavirus is God's thunderclap call for all people to repent and realign their lives with the infinite worth of Christ. ${ }^{13}$

- ANSWER 5. The coronavirus is God's call to his people to overcome self-pity and fear, and with courageous

\footnotetext{
Lee, "Theology in context."

Philips Gibbs, "Narrative and context in a practical theology for Papua New Guinea." Australian eJournal of Theology 9 (2007): 12.

John C Lennox, Where is God in a Coronavirus World? (UK: The Good Book Company, 2020).

John Piper, Coronavirus and Christ. (Wheaton, IL: Crossway, 2020).

Piper, Coronavirus and Christ, 61.

Piper, Coronavirus and Christ, 69.

Piper, Coronavirus and Christ. 73.

Piper, Coronavirus and Christ. 77.
} 
joy, to do the good works of love that glorify God. ${ }^{14}$

- ANSWER 6. In the coronavirus God is loosening the roots of settled Christians, all over the world, to make them free for something new and radical and to send them with the gospel of Christ to the unreached peoples of the world. ${ }^{15}$

These answers are very thought and theological provoking. There are some very "hard sayings" in them to absorb and ponder at a theological level. One cannot avoid being selective and counter argumentative. Piper in Answers 1-4 presents God as evil and the one who sent COVID-19. He does not in these answers try to defend God. In Theodicy, there is an attempt to extricate God from the perception that He is the cause and perpetrator of evil, a reflection of Calvinistic/Reformed doctrine.

Answers 5 and 6, are true expressions of the God in Christ believers know and serve, and they encapsulate the response and mission during and after COVID-19.

Both Lennox and Piper's work are a reminder that God is at work in this moment in history. God is not "an absentee landlord." He is omnipresent and transcendent. He is active in human history. He will not abandon or forsake His people during trying times.

God says to Israel:

But now, this is what the LORD says-- he who created you, O Jacob, he who formed you, O Israel: "Fear not, for I have redeemed you; I have summoned you by name; you are mine. When you pass through the waters, I will be with you; and when you pass through the rivers, they will not sweep over you. When you walk through the fire, you will not be burned; the flames will not set you ablaze. For I am the LORD, your God, the Holy One of Israel, your Saviour (Isa. 43:1-3 NRSV).

\section{Practical Considerations}

On 7 April 2020, WHO published an interim guidance document titled: "Practical considerations and recommendations for religious leaders and faith-based communities in the context of COVID-19."16

Here is an excerpt of the document:

WHO states that religious leaders, faith-based organizations, and faith communities can play a major role in saving lives and reducing illness related to COVID-19. These leaders, organisations and communities are a primary source of support, comfort, guidance, and direct health care and social service, for the communities they serve. Religious leaders of faith-based organizations and communities of faith can share health information to protect their own members and wider communities, which may be more likely to be accepted than from other sources. They can provide pastoral and spiritual support during public health emergencies and other health challenges and can advocate for the needs of the vulnerable. ${ }^{17}$

By sharing clear, evidence-based steps to prevent COVID-19, religious-inspired institutions can promote helpful information, prevent and reduce fear and stigma, provide reassurance to people in their communities, and promote health-saving practices. Religious leaders are integrated into their communities through service and compassionate networks and are often able to reach the most vulnerable with assistance and health information and identify those most in need. Religious leaders are a critical link in the safety net for vulnerable people within their faith community and wider communities. ${ }^{18}$

As such, WHO recommends and discusses in the document the following preventive measures:

- Prevent touching between people attending faith services

- Prevent touching or kissing of devotional and other objects that the community is accustomed to handling communally.

- Encourage healthy hygiene among participants in faith services and other activities when gatherings are permitted.

- Frequently clean worship spaces, sites, and buildings.

- Use technology to maintain community and continue worship.

- Use low-technology means to maintain faith-based practices in the community.

- Keeping the community connected.

\footnotetext{
14 Piper, Coronavirus and Christ. 87.

15 Piper, Coronavirus and Christ. 95.

16 WHO, "Practical considerations and recommendations for religious leaders and faith-based communities in the context of COVID-19," (2020): 1-5, accessed June 7, 2020. https://www.who.int/publications/i/item/practical-considerations-and-recommendations-for-religious-leaders-and-faith-based-communities-inthe-context-of-covid-19

17 WHO, "Practical considerations and recommendations."

18 WHO, "Practical considerations and recommendations."
} 
- Helping others.

- Helping members manage the onslaught of worrying news.

- Responding to situations of domestic violence.

- Offer special prayers for the sick alongside messages of hope and comfort.

In similar vein, on 10 July 2020, the Sierra Leone Government National COVID-19 Emergency Response Centre (NACOVERC) Freetown in collaboration with the Inter-Religious Council of Sierra Leone (IRCSL), provided Guidelines for the resumption of Congregational Worship. ${ }^{19}$ The following is an excerpts of the document:

1. The following guidelines will be jointly monitored by the working committee from the Inter Religious Council of Sierra Leone and the National / District National COVID19 Emergency Response Centre (NaCOVERC and DiCOVERCs). Weekly review meetings will be held.

2. Churches and Mosques will have responsibility for following the stipulated guidelines and ensuring internal monitoring mechanisms:

\section{A. Hygiene}

- Churches and Mosques should clean and disinfect their premises first before they are re-opened for worship. They should also be cleaned and disinfected in between services.

- Every worshipper must either use soap to wash their hands or apply sanitizers before being allowed to enter the Church/Mosque.

- Veronica buckets, soap and water or hand sanitizers should be provided at the entrance of every Church/Mosque.

- The use of toilet facilities to be responsibly monitored.

\section{B. Preventive measures}

- The temperature of every worshipper must be taken before admission into the Church/Mosque and people with a high temperature (37.5C/99.5F) should not be allowed into the Church/Mosque but be advised to go and seek medical attention.

- Everyone in the place of worship must properly wear a facemask during worship. Masks should not be removed or lowered when speaking or singing.

- There must be the use of sanitizers in Mosques/Churches as appropriate.

\section{Numbers and seating capacity}

- All places of worship must not exceed fifty percent (50\%) of the original capacity of the space taking into cognizance physical distancing of at least 6 feet. Churches and Mosques should map out the seating arrangements in the place of worship to ensure this.

- Churches can make use of classrooms and multipurpose halls for services where available, especially in big churches in order to accommodate more worshippers at a go. TV circuit and speakers can be used for those who are not inside the main auditorium.

- Multiple services can be held following the same guidelines as provided for in point 1 and 2 in this section for the Christians.

\section{Social distancing and safe practices}

- Social distancing should be observed in the sitting arrangement with two metres gap between worshippers. A seating arrangement should be marked and guided by the Church/Mosque.

- A church service must not exceed one and a half hours. In the case of the Muslims each daily prayer time should not exceed fifteen minutes while the Juma prayer must not exceed thirty (30) minutes.

- There should be a gap of 30 minutes between one Church service and another where there are multiple services to avoid crowding.

- Handshaking and hugging should be avoided before, during and after the worship.

- Different exit and entrance points will be used by worshippers (where possible) and movement will be done row after row.

- Social distancing should maintained during counselling.

\section{E. Ministration practices}

- There will be no Laying of Hands while praying for people.

\footnotetext{
19 Sierra Leone Government National COVID-19 Emergency Response Centre (NACOVERC) [2020]. "Guidelines for the resumption of Congregational Worship."
} 
- Communion will be served row after row and in individual cups or by intinction.

- Scaling down of the choir where necessary. Due to the high risk of spreading COVID-19, strict physical distancing of at least six feet must always be maintained by choristers.

- Offering bags/plates will be taken from row to row to avoid movement of people. The use of envelopes is advisable.

- Standing or individual microphones should be used at all times to avoid cross infection.

\section{F. Monitoring of compliance}

- An internal and monitoring committee should be constituted in every Mosque/Church to oversee compliance to the suggested guidelines.

- Medical awareness and health promotion should be done during Church services.

- All the measures outlined herein shall apply to all activities conducted in places of worship.

- Churches/Mosques that are found non-compliant with the above guidelines will be warned through the appropriate oversight structures; and subsequently shut down for repeat offenses.

\section{RECOMMENDATIONS AND CONCLUSION}

It is with great care that all stakeholders must look at the COVID-19 pandemic and respond in light of God's mission and actions. To participate in God's provision of the world at this time, the Church in Sierra Leone has to provide a consistent, sacrificial witness through a conscious theological contextualization that focus on the omnipotence and immanence of God over the long haul. The church as a faith community is a primary source of support, comfort, guidance, and direct health care and social service, for the people it serves. The church must provide pastoral and spiritual support during public health emergencies and other health challenges and must advocate for the needs of the vulnerable. The Church in Sierra Leone is integrated into the community through service and compassionate networks and is often able to reach the most vulnerable with assistance and health information and identify those most in need. The church is a critical link in the safety net for the vulnerable and needy within her community and wider communities.

Christians also have the responsibility to combat the spread of COVID-19 by adhering to the preventive measures and practical consideration recommended by the government and health experts. By sharing clear, evidencebased steps to prevent COVID-19, religious-inspired institutions can promote helpful information, prevent and reduce fear and stigma, provide reassurance to people in their communities, and promote health-saving practices. It has been predicted that the world will have to live with COVID-19 for many years to come. It is the church's mission to re-live her beliefs and teachings over the long haul. God will be with humanity every step of the way.

\section{ABOUT AUTHOR}

Prince Sorie Conteh holds doctorates in Systematic Theology and Religious Studies respectively. Prince is a minister of the Methodist Church Sierra Leone - presently in the Wilberforce Circuit. He is Professor of Theology and Religion, and Dean of Religious \& Interfaith Studies at the Ernest Bai Koroma University of Science and Technology. Prof Conteh has served academic institutions in Canada, the USA, South Africa, Ghana, Nigeria and Sierra Leone. He has published several works in Theology, Religion and Biblical Studies.

\section{BIBLIOGRAPHY}

Bergman, S. God in Context: A Survey of the Contextual Theology. UK: Ashgate Publishing Limited,2000.

Bevans, SB. Models of Contextual Theology Revised \& Expanded Edition. Maryknoll, NY: Orbis Books, 2005.

Flemming, D. Contextualization in the New Testament: Patterns for Theology and Mission. Downers Grove, IL: Intervarsity Press, 2005.

Gibbs, P. Narrative and context in a practical theology for Papua New Guinea. Australian eJournal of Theology 9 (2007): 4-12.

Lee, SC. "Theology in context." (2005). Accessed June 7, 2020. http://www.samlee.org/iSam/Home/Entries/2014/7/24_Theology_in_Context.html

Lennox, JC. Where is God in a Coronavirus World? UK: The Good Book Company, 2020.

Piper, J. Coronavirus and Christ. Wheaton, IL: Crossway, 2020.

Sierra Leone Government National COVID-19 Emergency Response Centre (NACOVERC) [2020]."Guidelines for the resumption of Congregational Worship."

WHO, "Practical considerations and recommendations for religious leaders and faith-based communities in the context of COVID-19" (2020):1-5. Accessed June 7, 2020.

https://www.who.int/publications/i/item/practical-considerations-and-recommendations-for-religious-leaders- 
and-faith-based-communities-in-the-context-of-covid-19

WHO, "UN releases US\$15 million to help vulnerable countries battle the spread of the coronavirus," (2020). Accessed June 7, 2020.https://www.who.int/publications/i/item/practical-considerations-and-recommendationsfor-religious-leaders-and-faith-based-communities-in-the-context-of-covid-19 